\title{
PEMBELAJARAN MENULIS ESAI DENGAN PENDEKATAN KONTEKSTUAL DAN MEDIA VIDEO DI KELAS XI SMA DARUL 'ULUM SUGIO
}

\author{
Ummu Rosyidatul, Mustofa, Nisaul Barokati Selirowangi \\ Universitas Islam Darul „Ulum Lamongan \\ ummuzain78@gmail.com, mustofa@unisda.ac.id, nisa@unisda.ac.id
}

\begin{abstract}
This research aims to download have been described: (1) the activity of the students on learning to write essays with a contextual approach and video media, (2) the activity of the teacher in the learning of essay writing with the contextual approach and video media, (3) student learning completeness on learning to write a contextual approach to essay and video media, and (4) student response on learning to write essays with the contextual approach and media video in class XI SMA Darul Ulum Sugio. This type of research is research qualitative and quantitative test results through the application of approaches and learning media. The population of this research is the learners class XI SCIENCES 2 SMA Darul Ulum Sugio. This research data obtained through observation sheets students, teacher observation sheets, test write essays, and question form. The results showed that the application of the approach Contextual Teaching and Learning (CTL) and video media on learning writing essay very effectively applied. Ditinjau of the student activity categorized either by percentage of $87 \%$ or effective to apply, review of teacher's activity categorized either by percentage amounted to $93.75 \%$ or effective to apply, review of ketuntasan learning students categorized either by a percentage of $75 \%$ effective or to be applied, in terms of response students categorized very well with the percentage of $91.96 \%$ or effective to apply.
\end{abstract}

Keywords: Essays, Contextual Teaching and Learning, and video media.

\begin{abstract}
Abstrak : Penelitian ini bertujuan untuk mendeskripsikan: (1) aktivitas siswa pada pembelajaran menulis esai dengan pendekatan kontekstual dan media video, (2) aktivitas guru pada pembelajaran menulis esai dengan pendekatan kontekstual dan media video, (3) ketuntasan belajar siswa pada pembelajaran menulis esai dengan pendekatan kontekstual dan media video, dan (4) respon siswa pada pembelajaran menulis esai dengan pendekatan kontekstual dan media video di kelas XI SMA Darul 'Ulum Sugio. Jenis penelitian ini adalah penelitian kualitatif dan kuantitatif melalui hasil uji coba penerapan pendekatan dan media pembelajaran. Populasi penelitian ini adalah peserta didik kelas XI MIPA 2 SMA Darul 'Ulum Sugio. Data penelitian ini diperoleh melalui lembar observasi siswa, lembar observasi guru, tes menulis esai, dan angket. Hasil penelitian menunjukkan bahwa penerapan pendekatan Contextual Teaching and Learning (CTL) dengan media video pada pembelajaran menulis esai sangat efektif diterapkan. Ditinjau dari aktivitas siswa berkategori baik dengan persentase sebesar $87 \%$ atau efektif untuk diterapkan, ditinjau dari aktivitas guru berkategori baik dengan persentase sebesar $93,75 \%$ atau efektif untuk diterapkan, ditinjau dari ketuntasan belajar siswa berkategori baik dengan persentase sebesar $75 \%$ atau efektif untuk diterapkan, ditinjau dari respon siswa berkategori sangat baik dengan persentase sebesar $91,96 \%$ atau efektif untuk diterapkan.
\end{abstract}

Kata kunci: Esai, Contextual Teaching and Learning, dan media video. 


\section{PENDAHULUAN}

Pembelajaran merupakan interaksi dua arah dari seorang guru dan peserta didik, di mana antara keduanya terjadi komunikasi (transfer) yang intens dan terarah menuju suatu target yang telah ditetapkan sebelumnya. Karena itu dalam pembelajaran terjadi dua aktivitas yakni belajar dan mengajar. Belajar merupakan aktivitas siswa sebagai proses menciptakan hubungan antara sesuatu (pengetahuan) yang sudah dipahami dan sesuatu (pengetahuan) yang baru. Sedangkan, mengajar merupakan aktivitas guru untuk menolong siswa memperoleh pengetahuan baru dan menghubungan dengan pengetahuan yang telah dimiliki, keterampilan, sikap, serta ide dan apresiasi yang menjurus kepada perubahan tingkah laku dan perkembangan siswa. Salah satu jenis pembelajaran wajib yang ada diseluruh jenjang sekolah yaitu Bahasa Indonesia.

Pembelajaran Bahasa Indonesia merupakan suatu pembelajaran yang mempunyai empat keterampilan berbahasa yang harus dimiliki siswa yaitu keterampilan menyimak, keterampilan berbicara, keterampilan membaca, dan keterampilan menulis (Dalman, 2012:3). Tarigan (dalam Marzuqi, 2013:1) mengatakan bahwa menulis merupakan suatu keterampilan berbahasa yang dipergunakan untuk berkomunikasi secara tidak langsung tidak tatap muka dengan orang lain. Menulis adalah suatu kegiatan penyampaian pesan dengan menggunakan bahasa sebagai mediumnya, pesan adalah isi atau muatan yang terkandung dalam tulisan (Akhadiah, 1997:3). Dari teori tersebut, dapat disimpulkan bahwa menulis merupakan sauatu kegiatan penyampaian pesan dengan medium bahasa yang telah disepakati bersama tanpa harus bertatap muka. Jika digabungkan dengan kata keterampilan, maka keterampilan menulis berarti kemampuan atau kecakapan seseorang dalam bidang tulis menulis yang lebih mengarah pada praktik atau implementasi dari teori tersebut. Salah satu jenis kompetensi keterampilan menulis dalam pembelajaran Bahasa Indonesia yang harus dicapai siswa yaitu menulis esai.

Menurut Webster Dictionary (dalam Komaidi, 2017:103), esai adalah sebuah tulisan, karangan, analisis, atau penafsiran tentang sesauatu. Kebanyakan dengan topik yang kurang lebih terbatas, dengan luas, gaya, dan metode bebas, walaupun pada umumnya dapat dibaca sekali duduk. Artinya, karangan yang tidak terlalu panjang. Pembelajaran menulis esai merupakan salah satu materi dalam KD mengonstruksi karya ilmiah di kelas XI. Dalam proses pembelajaran materi tersebut siswa dituntut aktif. Fakta di lapangan melihat proses pengembangan keterampilan menulis esai belum dapat dilakukan secara optimal. Seharusnya dalam pendidikan yang berkualitas setiap pembelajaran harus dapat mencapai tujuan pembelajarannya.

Agar dapat mencapai tujuan pembelajaran, maka guru harus mampu menghidupkan interaksi antara guru dengan siswa dan antara siswa dengan siswa lain. Guru harus mempersiapkan Rencana Pelaksanaan Pembelajaran (RPP) sebelum masuk ke dalam kelas agar dapat menguasai kelas dan mengontrol aktivitas apa saja yang akan dilakukan siswa ketika pembelajaran. Selain menyusun RPP sebelum melakukan kegiatan pembelajaran dalam kelas, guru juga harus menyiapkan perangkat pembelajaran yang lain seperti silabus. Sedangkan untuk mengetahui ketuntasan hasil belajar yang mengacu pada Kriteria Ketuntasan Minimum (KKM) yakni dengan memperoleh nilai 75 maka diadakan tes. Respon siswa merupakan hal yang penting untuk mengetahui keberhasilan pembelajran yang telah dilakukan, oleh karena itu perlu adanya angket.

Tujuan pembelajaran dapat dicapai jika dengan menerapkan pendekatan pembelajaran yang sesuai, yakni pendekatan pembelajaran yang berorientasi pada peserta didik. Salah satu 
jenis pendekatan yang dapat diterapkan dalam proses pembelajaran yaitu pendekatan kontekstual. Pendekatan kontekstual (Contextual Teaching and Learning) yang disingkat CTL adalah suatu pendekatan yang dapat mengarahkan siswa untuk bisa menerapkan pengetahuan yang dimiliki dalam situasi dunia nyata siswa. Menurut Trianto (2007:101) pendekatan kontekstual adalah konsep belajar yang membantu guru mengaitkan antara materi belajar dengan dunia nyata siswa dan mendorong siswa membuat hubungan antara pengetahuan dengan penerapannya dalam kehidupan seharihari. Elaine B.Johnson (dalam Rusman, 2013:187) mengatakan pembelajaran kontekstual adalah sebuah sistem yang merangsang otak untuk menyusun polapola yang mewujudkan makna.

Salah satu upaya untuk mewujudkan proses pengembangan keterampilan menulis esai yaitu dengan cara memilih media pembelajaran yang tepat. Bila tujuan atau kompetensi siswa bersifat menghafalkan kata-kata tentunya media audio yang tepat digunakan, jika tujuan atau kompetensi yang dicapai bersifat memahami isi bacaan maka media cetak yang lebih tepat digunakan, dan jika tujuan atau kompetensi yang dicapai bersifat motorik (gerak dan aktifitas) maka media film dan video bisa digunakan (Setyawan, 2011).

Jenis media yang dapat digunakan dalam pembelajaran menulis esai yaitu media video. Karena pembelajaran menulis esai menuntut siswa melakukan aktivitas yaitu membuat tulisan esai. Media video merupakan sarana komunikasi antara guru dengan siswa dalam bentuk pandang dengar. Video juga dapat menyajikan informasi, memaparkan proses, menjelaskan konsep-konsep yang rumit, mengajarkan keterampilan, menyingkat atau memperpanjang waktu, dan mempengaruhi sikap (Arsyad, 2014:50).

Sehubungan dengan beberapa paparan permasalahan di atas, karena penerapan pendekatan dan pemilihan media yang sesuai dengan tujuan pembelajaran atau kompetensi belum terlaksana dengan baik. Maka peneliti mengangkat judul Pembelajaran Menulis Esai dengan Pendekatan Kontekstual dan Media Video di Kelas XI SMA Darul „Ulum Sugio.

\section{METODE PENELITIAN}

Penelitian ini merupakan penerapan model pembelajaran kontekstual. Melalui pendekatan kontekstual peneliti ingin mengetahui pendekatan kontekstual jika diterapkan dalam keterampilan menulis esai dengan media video pada siswa kelas XI SMA Darul 'Ulum Sugio. Penelitian ini menggunakan pendekatan deskriptif kualitatif dan kuantitatif. Menurut Sugiono (2012:35), metode penelitian kualitatif diartikan sebagai metode penelitian yang berlandaskan (sebagai lawan ada eksperimen) dimana peneliti adalah sebagai instrumen kunci, teknik pengumpulan data dilakukan secara tringulasi (gabungan), analisis data bersifat induktif/kualitatif, dan hasil penelitian kualitatif lebih menekankan makna dari pada generalisasi. Penelitian dengan pendekatan kualitatif menekankan analisisnya pada proses penyimpulan deduktif dan induktif serta analisis pada dinamika hubungan antara fenomena yang diamati, dengan menggunakan logika ilmiah.

Penelitian deskripsi, yaitu menganalisis dan menyajikan fakta secara sistematik sehingga dapat lebih mudah dipahami dan disimpulkan (Azwar, 2011:6). Lebih lanjut lagi Azwar mengemukakan tujuan penelitian deskriptif yaitu menggambarkan secara sistematik, akurat fakta, dan karakteristik mengenai populasi atau mengenai bidang tertentu. Penelitian ini berusaha menggambarkan situasi atau kejadian.

Sedangkan penelitian deskriptif kuantitatif didasari oleh filsafat positivisme yang menekankan fenomenafenomena objektif dan dikaji secara kuantitatif. Maksimalisasi objektivitas 
desain penelitian ini dilakukan dengan menggunakan angka-angka, pengolahan statistik, struktur dan percobaan terkontrol. Penelitian ini merupakan penelitian yang bertujuan menjelaskan fenomena yang ada dengan menggunakan angka-angka untuk mencandarkan karakteristik individu atau kelompok (Syamsudin \& Damiyanti: 2011). Penelitian ini menilai sifat dari kondisi-kondisi yang tampak. Tujuan dalam penelitian ini dibatasi untuk menggambarkan karakteristik sesuatu sebagaimana adanya. Jadi, penelitian deskriptif kuantitatif diterapkan dalam penilaian dan respon siswa.

\section{HASIL DAN PEMBAHASAN}

Diketahui nilai persentase rata-rata aktivitas siswa dapat dihitung dengan menggunakan rumus sebagai berikut.

\section{Keterangan}

$\mathrm{P} \quad=$ Rata-rata persentase aktivitas seluruh siswa

$\sum \mathrm{S}=$ Jumlah nilai aktivitas seluruh siswa

$\mathrm{N}=$ Jumlah siswa

Perolehan nilai rata-rata di atas dapat disimpulkan bahwa proses pembelajaran menulis esai dengan pendekatan kontekstual dan media video ditinjau dari aktivitas siswa berkategori baik atau efektif untuk diterapkan di kelas XI MIPA 2 SMA Darul 'Ulum Sugio.

Nilai persentase rata-rata aktivitas guru dapat dihitung dengan rumus sebagai berikut.

$\mathrm{P}$

Keterangan

$\mathrm{P} \quad=$ Perolehan nilai

$\sum \mathrm{S}=$ Jumlah skor yang diperoleh

$\mathrm{N}=$ Jumlah skor total

Perolehan nilai tersebut dapat disimpulkan bahwa proses pembelajaran menulis esai dengan pendekatan kontekstual dan media video ditinjau dari aktivitas guru berkategori baik atau efektif untuk diterapkan di kelas XI MIPA 2 SMA Darul 'Ulum Sugio.

Jumlah siswa yang tuntas belajar adalah sebanyak 12 siswa sedangkan yang tidak tuntas belajar terdapat 4 siswa. Persentase ketuntasan belajar siswa dalam satu kelas dapat dihitung dengan menggunakan rumus sebagai berikut.

$\mathrm{P}$ -

Keterangan

$\mathrm{P}=$ Persentase tingkat ketuntasan belajar seluruh siswa

$\mathrm{FX}=$ Banyaknya siswa yang tuntas belajar

$\mathrm{N}=$ Jumlah seluruh siswa

Berdasarkan hasil perhitungan nilai tingkat ketuntasan belajar siswa dapat disimpulkan bahwa proses pembelajaran menulis esai dengan pendekatan kontekstual dan media video ditinjau dari ketuntasan belajar siswa berkategori baik atau efektif untuk diterapkan di kelas XI MIPA 2 SMA Darul 'Ulum Sugio.

Rata-rata respon siswa sebesar $91.96 \%$. Perolehan nilai rata-rata tersebut diperoleh dari perhitungan dengan rumus berikut.

$\mathrm{P}$ -

Keterangan

$\mathrm{P} \quad=$ Rata-rata persentase respon seluruh siswa

$\sum \mathrm{R}=$ Jumlah nilai respon seluruh siswa

$\mathrm{N}=$ Jumlah seluruh siswa

Berdasarkan hasil perhitungan nilai rata-rata persentase respon seluruh siswa dapat disimpulkan bahwa proses pembelajaran menulis esai dengan pendekatan kontekstual dan media video ditinjau dari respon siswa berkategori sangat baik atau efektif untuk diterapkan di kelas XI MIPA 2 SMA Darul 'Ulum Sugio.

\section{Simpulan}

Berdasarkan penelitian yang telah dilakukan di kelas XI MIPA 2 SMA Darul 'Ulum Sugio, dapat disimpulkan bahwa penerapan pendekatan Contextual Teaching and Learning (CTL) dengan 
media video pada pembelajaran menulis esai sangat efektif diterapkan, dengan hasil sebagai berikut. Proses pembelajaran menulis esai dengan pendekatan kontekstual dan media video ditinjau dari aktivitas siswa berkategori baik dengan persentase sebesar $87 \%$ atau efektif untuk diterapkan. Proses pembelajaran menulis esai dengan pendekatan kontekstual dan media video ditinjau dari aktivitas guru berkategori baik dengan persentase sebesar $93,75 \%$ atau efektif untuk diterapkan. Proses pembelajaran menulis esai dengan pendekatan kontekstual dan media video ditinjau dari ketuntasan belajar siswa berkategori baik dengan persentase sebesar $75 \%$ atau efektif untuk diterapkan. Terdapat 16 siswa di kelas XI MIPA 2, 12 siswa tuntas dan 4 siswa tidak tuntas pada tahap tes. Proses pembelajaran menulis esai dengan pendekatan kontekstual dan media video ditinjau dari respon siswa berkategori sangat baik dengan persentase sebesar $91,96 \%$ atau efektif untuk diterapkan di kelas XI MIPA 2 SMA Darul 'Ulum Sugio.

\section{DAFTAR RUJUKAN}

Akhadiah, dkk. 1998. Pembinaan Kemampuan Menulis Bahasa Indonesia. Jakarta: Erlangga. Arsyad, Azhar. 2014. Media Pembelajaran. Jakarta: Rajawali Pers

Azwar, Saifuddin. 2012. Reliabilitas dan Validitas. Yogyakarta: Pustaka Pelajar.

Heryansyah, Tedy. 2017. "LangkahLangkah Penting dalam Membuat Esai". (online)

(http://blog.ruangguru.com;) diakses 21 Desember 2018

Komaidi, Didik. 2017. Panduan Lengkap Menulis Kreatif: Proses, Keterampilan, dan Profesi. Yogyakarta: Araska.

Marzuqi, Iib. 2013. Keterampilan Menulis dalam Pembelajaran Bahasa dan Sastra Indonesia: Teori dan
Implementasi. Surabaya: CV. ISTANA.

Rusman. $2013 . \quad$ Model-Model

Pembelajaran: Mengembangkan

Profesionalisme Guru. Jakarta: PT.

Rajagrafindo Persada.

Sanjaya, Wina. 2012. Strategi

Pembelajaran Berorientasi Standar

Pendidikan. Jakarta: Kencana.

Sugiyono. 2012. Metode Penelitian

Kuantitatif, Kualitatif, dan $R \& D$.

Bandung: Alfabeta.

Trianto. 2014. Mendesain Model Pembelajaran Inovatif, Progresif, dan Kontekstual: Konsep, Landasan, dan Implementasi pada Kurikulum $2013 \quad$ (Kurikulum Tematik Integratif/TKI). Jakarta: Prenadamedia Group. 